-in just those cases, in fact, in which calculation is laborious. It has the defect of logarithmic calculation in a very exaggerated degree, inasmuch as it is not accurate, but in very many cases this is of no great importance, since the degree of accuracy attainable is abundantly sufficient for all practical requirements. Scales possess one great advantage over methods of calculation, in that it is not possible to make the mistakes which so easily enter into arithmetical calculations. If they be accurately constructed, the modes of using them are so simple that there is scarcely a possibility of making a mistake, and we can predict beforehand the degree of accuracy which may be relied on. For engineering and other simple calculations we believe that these scales, and others like them, will be more and more used as they become more widely known.

\section{THE FISHERY BOARD FOR SCOTLAND}

THE second Annual Report of the Fishery Board for Scotland has just been issued, and contains much of scientific as well as economic interest.

The first Royal Commission on British Fisheries was founded in 1630. Immediately after the Union the fishing industry almost ceased to exist, owing apparently to the enactment of salt duties. In 1727 an Act was passed, by which the Board of Trustees for Manufactures and Fisheries was created, which, besides encouraging and superintending the fisheries, was empowered to pay certain "bounties" to the herring "busses," and offer premiums to the fishermen who first discovered herrings during each season at the different parts of the coast. In 1808 "An Act for the further encouragement and better regulation of the British White Herring Fishery" was passed. The Commission appointed to carry it into effect had charge of the whole fisheries of the British coasts, and later of the Isle of Man, and, in addition to granting bounties, had 3000 l. placed at their disposal for encouraging the fishermen to use larger boats, so that they might go further out to sea. The Commissioners stationed officers at the chief coast fishing centres both in England and Scotland, and later two officers to the port of London, from whence large consignments of herring were sent abroad. The Admiralty provided a ship of war to assist in the work of superintending, and in 18 I $_{5}$ a cutter was obtained for use in the Firth of Forth, and afterwards at other parts of the coast. Whatever influence the Commissioners had in improving the supply of fish and in developing the fisheries cannot now be estimated, but there can be no doubt that they rendered inmense service in collecting statistics, which were till recently the only reliable fishery statistics extant, and of sufficient value to have justified the existence of the Board of Fisheries, even though all other work done were left out of consideration. From the statistics so collected, a valuable chart (Appendix A, Table VIII.) has been prepared by Mr. Robertson, one of the clerks of the Board, which shows at 'once the take of herring from 1809 to 1882 ; while Appendix $C$ gives fresh statistics of the quantities and values of white fish and shell-fish. In 1820 the officers were instructed to take the cod and ling fishery under their charge; in 1821 the bounty for encouraging deep-sea fishing was withdrawn; in 1830 all bountics were repealed, and part of the money set aside for the erection of piers and harbours. In 1839 the Secretary of the Board of Manufactures was appointed Secretary of the Fishery Commissioners, and soon after this the Commissioners began to direct their attention to some of the hitherto neglected problems connected with the fisheries. In 1836 the question arose whether or not sprats were young herring, which Dr. Knox, who was appealed to, decided in the negative. This question having led the Commissioners to take an interest in the young herring, and to see the necessity of gaining some definite information as to the growth, food, and habits of the fish, Mr. Henry Goodsir carried on investigations in the Firth of Forth during 1843-44, from which it was ascertained that the food of the herring consists chiefly of young Crustacea. From the Report of 1846 it is evident that the Commissioners were acquainted with the fact that the herring ova sink and adhere to whatever they come in contact with. In 1850 the Engiish stations were discontinued, and in 1856 another step in the right direction was taken, at the request of Dr. Buys Ballot, who invited those engaged in the great herring fishery to make observations in order to ascertain the circumstances likely to lead to the most profitable fishing and to enable them to make a herring chart. According to instructions issued by the Board of Trade, samples of herring collected on various parts of the coast of Scotland were forwarded to it, but no record is made of their examination. In I 860 complaints of the effects of trawling for white fish in the spawning grounds having led to another inquiry, Prof. Allmann decided that there was no evidence to show that trawling was likely to do injury to the spawning ground. No continuous investigations were, howcver, carried on by the Board, a new complaint being merely followed by a new inquiry or new Commission. Had the Board been provided with funds nccessary to carry on continuous investigations as to growth, food, and habits of the herring and other useful fishes, much valuable information might have been obtained and great expense of Commissions of Inquiry avoided. It is therefore a matter of surprise and regret that, notwithstanding the example of other States, the influence of the Fisheries Exhibitions, and the demand for more information, the Treasury has not yet provided the new Board with sufficient funds. Another agitation arose in 1860 , which led to the appointment of Prof. Allmann and Dr. Lyon Playfair, C.B., to inquire into the effects of trawling at the Fluke Hole, Pittenweem, and about the same time Dr. Playfair and Vice-Admiral Henry Dundas were requested to inquire into the claims of the sprat fishermen of the Firth of Forth. The agitation continuing, a Royal Commission, consisting of Dr. Lyon l'layfair, C.B., Prof. Huxley, F.R.S., and Lieut.-Col. Francis Maxwell, was appointed in $\mathrm{I} 862$ to inquire as to "the operation of the Acts relating to trawling for Herring on the Coasts of Scotland." The Report of this Commission is especially interesting, because it contains the results of the inquiries made by Prof. Allmann during the winter and spring of I 862 as to the nature of herring ova. The investigations made by him proved that the spawn of the herring "was deposited on the surface of stones, shingle, and gravel, on old shells and coarse sea-sand, and even on the shells of small living crabs and other Crustacea," and that it "adhered tenaciously to whatever matter it happened to be deposited on." The Report also contained a valuable chapter on the natural history of the herring, in which it is pointed out for the first time that there are two principal spawning periods, an autumn period with August and September as the two principal months, and a spring period with February and March as the principal months.

In 1873 the Scottish Meteorological Society began a series of inquiries with a view of determining how far the temperature of the sea and other meteorological conditions affect the migration of the herrings. From information obtained it was concluded ( 1 ) that the catch of herrings is less during any season with a high temperature than during a corresponding season with a low temperature ; (2) that if the catch of herrings is higher in one district than in the other, the catch is greatest in the district with the lowest temperature; (3) that when the surface temperature is higher than the temperature lower down, the herrings seek the deeper water. It will be seen from the foregoing statement that the officers of the old Board were not utilised for making investigations. Important facts were however established as to (I) the 
nature of the spawn ; (2) the periods of spawning; (3) the food of the herring. In 1882 the Board of British White Herring Fishery having been dissolved, the present Fishery Board for Scotland was established, to carry on the work of superintending the fisheries, and also to "take such measures for their improvement as the funds under their ministration may admit of." The Board soon recognised the absolute necessity of obtaining accurate scientific information as to the habits and life-history of the food fishes, and therefore appointed a Committee consisting of Prof. Cossar Ewart (convener), Sir James R. Gibson Maitland, Sheriff Forbes Irvine, and J. Maxtone Graham, to carry on scientific investigations.

The preliminary report of work done in the autumn of 1883 and at Ballantrae has been already given in NATURE. The Admiralty has been pleased to provide a gunboat, H.M.S. Jackal, Lieut. Prichett, R.N., commander, to help in the investigations and inspect the spawning grounds, and the Boord has also at its service the cruiser Vigilant, both of which vessels have done excellent work, though it is desirable that they should be replaced by others more capable of sea-going service. The Board is fortunate in having in its service a large staff of intelligent Qfficers not only familiar with all the practical aspects of the fishing industry but deeply interested in the scientific work of the Board, which they aid to their utmost power. The future lines of inquiry which the Board hope to undertake include (I) the examination of the spawning beds round the Scottish coast; (2) the determination of the food of useful fishes; (3) the investigation of percentage of young herring, \&c., destroyed by present modes of fishing ; $(4)$ the influence of sea-birds, \&c., on supply of fishes; (5) study of spawning, nature of the eggs, and general life and development of herring, \&c. ; (6) best means of restocking deserted fishing grounds; (7) of increasing artificially the supply of shell-fish; and (8) of inquiry into fungi, \&c., hurtful to fish life. The Board is fitting up a marine station at St. Andrew's, where Prof. McIntosh will make investigations for the Board, whilst similar work will be carried on in the Moray Firth. We trust that the impetus given to and the interest excited in the work of the Board may produce most favourable results, both economic and scientific.

We hope to return in a future number to some of the papers of specially scientific interest contained in this Report.

\section{THE HISTORY OF A TYPHOON}

$\mathrm{P}$ ERE DECHEVRENS, the indefatigable head of the Meteorological and Magnetic Observatory at Zikawei near Shanghai, has just published the first part of a work dealing with the typhoons of $\mathrm{r} 882$. The present instalment is confined to those of the months of July and August in that year. The various plans and maps showing the course of the typhoons, and the height of the barometer at various times during their progress in different place;, are so "fabulously complicated," to use the writer's phrase, that he fears more than one reader will regard his pamphlet as a work of imagination. Père Dechevrens, however, has had the advantage of observation; made in China, Japan, and the Philippines by captains of vessels, lighthouse keepers, Customs officers, \&c., such as have never before been made of any cyclone. Chinese typhoons, as he points out, fortunately for the meteorologist, though unfortunately for the navigator, ravage places visited by the ships of all nationalities, and hence with a little arrangement and organisation these phenomena may be easily studied in these regions. The Shanghai Chamber of Commerce and Sir Robert Hart have arranged for a regular supply to Père Dechevrens of a regular series of meteorological observations, and one of the earlicst results is the pamphlet now before us. As a consequence of these wide and varied observations, the writer, while acknowledging the work of his predecessors, such as Spindler in Russia, Knipping in Japan, and Faura in Manila, claims that, while they were only able to give the history, as it were, of incidents in the life of a typhoon, he, thanks to the vast number and extent of the documents placed in his hands, has been able to connect these various fragments, and to trace the history of several typhoons from their cradle in equatorial maritime regions to their grave in the North Pacific Ocean. This, in his own words, is what Père Dechevrens has now done in his pamphlet. The first section deals with July I 882 , and it is divided into several sub-sections, dealing with the formation of a typhoon on July 5, its progress in the China Sea, and a first separation or offshoot from the main storm, its progress on the mainland of China, the second typhoon of July ro in the China Sea, and before Hong Kong, in the Formosa Channel, "its flight towards India, and its disappearance in the north of China," and finally an account of a typhoon in Hong Kong and IndoChina. The typhoons of August are discussed in a similar manner in detail, the conclusions being supported by observations made in all parts of the China seas and coasts. There are also a large number of diagrams. In his recapitulation the writer points out that, though he has been speaking of various typhoons, such as that in the Formosa Channel, in Hong Kong, \&c., he has really been dealing with only one widespread storm, which, during its life of fifteen days, visited every coast from the equator to Siberia, and from the extreme east of Japan to the western frontier of India. The character which Père Dechevrens gives the phenomenon he has so carefully studied is this:- "It allows itself to stray with the greatest ease outside the straight path. In a truly headlong way it throws itself against all obstacles, gets into difficulties from which it can scarcely extricate itself, wastes its energies in whirlwinds, often powerless, which it abandons readily, goes, returns, hastens, stops still, in a word revolving always in the same circle, until, having expended all its strength, it disappears miserably at that part of the Pacific which in a short time would have been able to give it the necessary vigour to sustain a longer career, and, like many others, to reach the shores of North America, or at least, if retarded by the violence of the North Pacific, as far as Behring Straits." Three facts which this study renders prominent are :-

I. The extreme facility with which these typhoons divide and subdivide.

2. The mutual attraction and repulsion of atmospheric disturbances (whirlwinds).

3. The absence of the south-west monsoon in the Philippine Islands.

In his recapitulation these three points are discussed at some length in the summary, and we merely indicate them here to show the student what he may expect in this painstaking and learned publication.

\section{HEALTHY SCHOOLS ${ }^{1}$}

THERE can be no more appropriate product of an exhibition which seeks to illustrate the two problems of health and education than a handbook on healthy schools. Within the brief space of 72 pages Mr. Paget has brought together here some of the most important counscls which experience has suggested on structure, drainage, fitting, food, recreation, ventilation, and other
conditions on which the health of children in schools depends. No school manager or teacher can read it without much profit ; and the executive of the Exhibition has done the community a service by placing within its reach in a succinct and readable form so much practical knowledge and fruitful suggestion.

x " Healthy Schools." By Charles E. Paget, Medical Officer of HeaIth for the Westmoreland Combined Sanitary District; Honorary Secretary of the Fpidemiological Society of London.
Handbook Series. (Clowes and Sons.) 